\title{
KULTUR EMBRIO MERBAU (Intsia bijuga OK.) PADA MEDIA MURASHIGE \& SKOOG (MS) DIPERKAYA DENGAN ZAT PENGATUR TUMBUH BAP, GA3 dan IBA
}

\section{(Embryo Culture in Merbau [Intsia bijuga OK.] towards Murashige \& Skoog [MS] Media that Enriched by BAP, GA, and IBA Plant Growth Substances)}

\author{
Samuel Bram Sainawal ${ }^{1}$ Julius D. Nugroho ${ }^{1 凶}$ dan Francina F. Kesaulija ${ }^{1}$ \\ Jurusan Kehutanan, Fakultas Kehutanan Universitas Papua Manokwari, Papua Barat, \\ 98314. Tlp/Fax: +62986211065 . \\ ${ }^{\square}$ Penulis Korespondensi: Email: jd nugroho2004@yahoo.com \\ Diterima: 21 Oct 2017| Disetujui: 25 Nov 2017
}

\begin{abstract}
Abstrak
Tujuan penelitian ini untuk mencari konsentrasi dan kombinasi zat pengatur tumbuh (IBA, BAP dan $\mathrm{GA}_{3}$ ) yang cocok guna pertumbuhan embrio dari tanaman Merbau (Intsia bijuga OK.) pada media Murashige \& Skoog (MS) untuk mendapatkan tanaman yang sempurna melalui teknik kultur jaringan. Metode yang digunakan dalam penelitian ini adalah metode eksperimen dengan teknik observasi menggunakan perhitungan statistik deskriptif. Hasil penelitian ini menunjukkan bahwa penggunaan eksplan embrio merbau (Intsia bijuga $\mathrm{OK}$.) yang terbaik adalah menggunakan media dengan zat pengatur tumbuh pada media MS + $\mathrm{GA}_{3} 2$ ppm dengan persen hidup $100 \%$ dan memiliki persen eksplan kontaminasi $0 \%$. Pertumbuhan tunas pada perlakuan ini terjadi pada umur 86 hari dengan rata-rata pertumbuhan tunas sebesar $\pm 0,2 \mathrm{~cm}$, persen eksplan bertunas $0 \%$, pada pertumbuhan terbentuknya akar pada minggu ketujuh dari pengamatan.
\end{abstract}

Kata kunci: Intsia bijuga, embrio, zat pengatur tumbuh, media tanam, eksplan

\begin{abstract}
This study is focusing on determining an appropriate concentration as well as combination from plant growth substances (IBA, BAP dan $G A_{3}$ ) for growing an embryo of Intsia bijuga tree species on media of Murashige \& Skoog (MS) through plant tissue isolation technique. Method used in this study was experiment by way of observation and simple descriptive statistic analysis to generate better solution from the analysis. The results noticed that the best use of Intsia bijuga explant embryo was by using media and plant growth substance of $M S+G A_{3} 2$ ppm with a life percentage of $100 \%$ and had a $0 \%$ of explant contamination. The growth of bud in this treatment was occurred in 86 days with the average growth of \pm $0.2 \mathrm{~cm}$, bud explant percentage of $0 \%$, and the initiation of root growth at the seventh week of observation.
\end{abstract}

Keywords: Intsia bijuga, embryo, plant growth substances, growth media, explant

\section{PENDAHULUAN}

Merbau (Intsia bijuga OK.) merupakan salah satu jenis kayu niagawi asli Papua yang menghasilkan kayu dari Hutan Produksi. Kayu merbau memiliki nilai komersial yang tinggi karena sifat keawetan dan kualitas yang sangat baik. Saat ini merbau didorong untuk dikembangkan dalam skema hutan tanaman industri. Kultur jaringan 
merupakan teknik perbanyakan tanaman dengan cara mengisolasi bagian tanaman seperti daun, mata tunas, serta menumbuhkan bagian-bagian tersebut dalam media buatan secara aseptik yang kaya nutrisi dan zat pengatur tumbuh dalam wadah tertutup yang tembus cahaya sehingga bagian tanaman dapat memperbanyak diri dan bergenerasi menjadi tanaman lengkap. Prinsip utama dari teknik kultur jaringan adalah perbayakan tanaman dengan menggunakan bagian vegetatif tanaman menggunakan media buatan yang dilakukan di tempat steril (Muhiklaten 2011).

Metode kultur jaringan dikembangkan untuk membantu memperbanyak tanaman, khususnya untuk tanaman yang sulit dikembangbiakkan secara generatif. Bibit yang dihasilkan dari kultur jaringan mempunyai beberapa keunggulan, antara lain: mempunyai sifat yang identik dengan induknya, dapat diperbanyak dalam jumlah yang besar sehingga tidak terlalu membutuhkan tempat yang luas, mampu menghasilkan bibit dengan jumlah besar dalam waktu yang singkat, kesehatan dan mutu bibit lebih terjamin, kecepatan tumbuh bibit lebih cepat dibandingkan dengan perbanyakan konvensional (Muhiklaten 2011). Penelitian ini bertujuan untuk mencari konsentrasi dan kombinasi zat pengatur tumbuh (IBA, BAP dan $\mathrm{GA}_{3}$ ) yang cocok untuk pertumbuhan embrio Merbau (Intsia bijuga Ok.) pada media Murashige \& Skoog (MS) dengan menggunakan teknik kultur jaringan.

\section{METODE PENELITIAN}

Lokasi penelitian ini dilaksanakan pada Laboratorium Silvikultur yang bertempat di Kampus Fakultas Kehutanan
Unipa Manokwari Provinsi Papua Barat dengan durasi waktu penelitian selama \pm 3 bulan.

\section{Metode Penelitian}

Metode yang dipakai dalam penelitian ini adalah metode eksperimen dengan teknik observasi menggunakan perhitungan statistik deskriptif. Penelitian ini menggunakan embrio merbau.

Perlakuan dari penelitian ini adalah sebagai berikut :

A : Media MS 0 (Kontrol)

$\mathrm{B}:$ Media $\mathrm{MS}+\mathrm{GA}_{3} 2 \mathrm{ppm}$

$\mathrm{C}:$ Media MS + BAP $4 \mathrm{ppm}$

$\mathrm{D}$ : Media $\mathrm{MS}+\mathrm{GA}_{3} 2 \mathrm{ppm}+\mathrm{BAP} 2$ ppm + IBA 1 ppm

Penelitian ini terdiri dari 4 perlakuan dan 7 ulangan sehingga diperoleh 28 satuan percobaan.

\section{Pelaksanaan Penelitian}

Pelaksanaan Penelitian yang dilakukan dalam perbanyakan tanaman dengan teknik kultur jaringan adalah:

\section{Sterilisasi Alat dan Bahan}

Alat dan bahan yang digunakan dalam melakukan kultur jaringan harus dalam keadaan bersih dan steril. Sterilisasi dilakukan dengan menggunakan autoclave dengan tekanan berkisar antara 15 psi - 20 psi. Sterilisasi dilakukan dengan cara autoclave diisi air sampai dengan batas yang ditentukan kemudian masukkan botol-botol kultur, botol berisi air aquades $100 \mathrm{ml}$, yang sebelumnya telah dibungkus dengan kertas kedalam autoclave kemudian tutup rapat dan nyalakan autoclave. Tunggu sampai air yang didalamnya mendidih dan tekanan yang ditentukan lalu atur waktunya selama 20 menit. Setelah itu autoclave dimatikan lalu tunggu sampai tekanannya turun ke angka nol (0) dan biarkan sampai 
agak dingin. Buka autoclave dan keluarkan botol-botol kultur dan botol berisi air aquades $100 \mathrm{ml}$ tersebut kemudian disimpan di ruang kultur sampai saat akan digunakan nanti.

Sterilisasi Laminar Air Flow Cabinet (LAFC) dilakukan sesaat sebelum melakukan pengkulturan eksplan. Caranya yaitu dengan menyemprotkan alkohol $70 \%$ kemudian dikeringkan dengan tisu. Nyalakan lampu UV selama 30 menit dalam keadaan tertutup. Lampu UV dimatikan kemudian nyalakan blower, lampu TL dan api bunsen yang menandakan bahwa LAFC siap digunakan.

\section{Pembuatan Media}

Media yang digunakan adalah media dasar Murashige \& Skoog (MS), dengan perlakuan MS 0 (kontrol), Media MS + GA3 2 ppm, Media MS + BAP 4 ppm, Media MS + GA3 2 ppm + BAP 2 ppm + IBA 1 ppm dan dibuat masing-masing sebanyak $500 \mathrm{ml}$. Tahapan pembuatan media Murashige \& Skoog (MS) yaitu pertama-tama masukan aquades kedalam gelas piala sebanyak $200 \mathrm{ml}$ lalu masukkan larutan stok media MS (larutan stok A $20 \mathrm{ml}$, larutan stok B $20 \mathrm{ml}$, larutan stok C $10 \mathrm{ml}$, larutan stok D 10 $\mathrm{ml}$, larutan stok E $5 \mathrm{ml}$, larutan stok F 5 $\mathrm{ml})$, larutan stok vitamin $0,5 \mathrm{ppm}$, gula 15 $\mathrm{g}$ lalu diaduk dengan menggunakan magnetik stirrer sampai larut.

Kemudian masukkan zat pengatur tumbuh pada masing-masing media tanam yaitu Indole Butiric Acid (IBA), Benzil Amino Purin (BAP), Gibberelic Acid $\left(\mathrm{GA}_{3}\right)$ dengan konsentrasi yang ditetapkan. Tambahkan aquades sampai mendekati batas tera kemudian ukur $\mathrm{pH}$ dengan kertas lakmus. $\mathrm{pH}$ yang diharapkan adalah 5,5-5,8 jika $\mathrm{pH}<5,8$ maka ditambahkan larutan $\mathrm{NaOH}$ dan jika
$\mathrm{pH}>5,8$ maka ditambahkan larutan $\mathrm{HCl}$. Tambahkan aquades sampai batas tera lalu masukkan agar-agar $8 \mathrm{gr} / \mathrm{l}$ dan diaduk sampai larut sambil dipanaskan diatas hot plate sampai mendidih. Media dituangkan ke dalam botol kultur masing-masing 20 $\mathrm{ml}$, tutup dengan plastik transparan lalu diikat dengan karet gelang kemudian disterilkan menggunakan autoclave dengan tekanan berkisar antara 15 psi 20 psi selama 25 - 30 menit.

\section{Pengambilan Eksplan}

Eksplan yang digunakan adalah embrio Intsia bijuga, biji diperoleh dari hutan tanaman di Taman Wisata Alam Gunung Meja.

\section{Sterilisasi Eksplan}

Dalam pelaksanaannya proses sterilisasi merupakan tahapan yang menentukan keberhasilan dari kultur jaringan. Eksplan yang digunakan adalah embrio merbau. Tahapannya adalah biji Intsia bijuga dicuci bersih dengan air untuk menghilangkan kotoran yang melekat pada biji tersebut setelah bersih biji dikocok dengan klorox 100\% selama 20 menit. Kulit biji dilukai atau dipotong dengan pisau cutter lalu direndam dengan air panas dengan suhu $70-80^{\circ} \mathrm{C}$ hingga kulit merbau yang keras menjadi lebih lunak. Biji dikocok kembali dengan klorox $30 \%$ selama 10 menit lalu bilas dengan air steril. Biji yang sudah steril dibelah dengan pisau steril guna mengambil embrio yang terdapat pada biji. Embrio yang sudah diperoleh kemudian dikocok dengan betadine lalu ditiriskan dengan kertas saring steril.

\section{Penanaman Eksplan}

Eksplan yang sudah steril diambil dengan pingset dan dimasukkan pada media tanam yang telah disiapkan. Buka tutup plastik botol yang sudah disterilkan 
dengan autoclave lalu dipanaskan pada lubang botol dengan tujuan agar terhindar dari kontaminasi yang diperoleh dari bakteri maupun fungi. Pingset yang digunakan terlebih dahulu dicelupkan pada alkohol lalu ujung pingset dipanaskan oleh api bunsen agar pingset lebih steril. Setelah eksplan ditanam pada media lalu botol kembali ditutup dengan plastik transparan dan diikat dengan karet gelang serta dililit kembali dengan plastik wrap. Setelah itu diberi label kemudian diletakkan pada rak kultur dalam ruangan kultur bersuhu $\pm 25^{\circ} \mathrm{C}$.

\section{Pengamatan dan Evaluasi}

Pengamatan dilakukan setiap hari untuk melihat perkembangan dari eksplan. Namun pengambilan data eksplan yang hidup, eksplan yang terkontaminasi, eksplan yang berkalus dan jumlah akar dilakukan setiap minggu setelah inokulasi. Sedangkan persen hidup eksplan, panjang akar, jumlah tunas dan tinggi tanaman diukur pada hasil penelitian.

\section{Variabel Pengamatan}

Variabel yang diamati adalah sebagai berikut :

1. Persen Eksplan Hidup Eksplan hidup $(\%)=\frac{\text { Jumlah eksplan yang tumbuh }}{\text { Jumlah seluruh eksplan yang dikulturkan }} \times 100$

2. Persen Eksplan Kontaminasi

Eksplan Kontaminasi $(\%)=\frac{\text { Jumlah eksplan yang terkontaminasi }}{\text { Jumlah seluruh eksplan yang dikulturkan }} \times 100$

3. Persen Eksplan Browning

Eksplan Browning $(\%)=\frac{\text { Jumlah eksplan yang browning }}{\text { Jumlah seluruh eksplan yang dikulturkan }} \times 100$

4. Persen Eksplan Memanjang

Eksplan Memanjang $(\%)=\frac{\text { Jumlah eksplan yang memanjang }}{\text { Jumlah seluruh eksplan yang dikulturkan }} \times 100$

5. Persen Eksplan Berakar

$$
\text { Eksplan Berakar }(\%)=\frac{\text { Jumlah eksplan yang berakar }}{\text { Jumlah seluruh eksplan yang dikulturkan }} \times 100
$$

6. Persen Eksplan Bertunas

Eksplan Bertunas $(\%)=\frac{\text { Jumlah eksplan yang bertunas }}{\text { Jumlah seluruh eksplan yang dikulturkan }} \times 100$

7. Waktu Terbentuknya Akar

8. Waktu Terbentuknya Tunas

\section{Analisis Data}

Data yang diperoleh dianalisis dengan menggunakan perhitungan merata dan hasilnya ditampilkan dalam bentuk tabel dan gambar.

\section{HASIL DAN PEMBAHASAN}

\section{Hasil}

Berdasarkan hasil penelitian pertumbuhan embrio Intsia bijuga secara in vitro dalam media MS yang telah diamati disajikan pada tabel 1 . 
Tabel 1. Respon kultur embrio Intsia bijuga yang dikulturkan pada media MS terhadap kombinasi zat pengatur tumbuh

\begin{tabular}{ccccccccc}
\hline Perlakuan & $\begin{array}{c}\text { EH } \\
(\%)\end{array}$ & $\begin{array}{c}\text { EK } \\
(\%)\end{array}$ & $\begin{array}{c}\text { EB } \\
(\%)\end{array}$ & $\begin{array}{c}\text { EM } \\
(\%)\end{array}$ & $\begin{array}{c}\text { EA } \\
(\%)\end{array}$ & $\begin{array}{c}\text { ET } \\
(\%)\end{array}$ & $\begin{array}{c}\text { Waktu } \\
\text { terbentuknya } \\
\text { akar }\end{array}$ & $\begin{array}{c}\text { Waktu } \\
\text { terbentuknya } \\
\text { tunas }\end{array}$ \\
\hline A & 85 & 15 & 57 & 85 & 42 & 28 & Minggu ke 5 & Minggu ke 6 \\
B & 100 & 0 & 42 & 100 & 71 & 57 & Minggu ke 4 & Minggu ke 5 \\
C & 71 & 29 & 14 & 71 & 28 & 14 & Minggu ke 7 & Minggu ke 8 \\
D & 42 & 58 & 71 & 14 & 28 & 0 & Minggu ke 7 & - \\
\hline
\end{tabular}

Keterangan : $\mathrm{A}=\mathrm{MS} 0, \mathrm{~B}=\mathrm{MS}+\mathrm{GA}_{3} 2 \mathrm{ppm}, \mathrm{C}=\mathrm{MS}+\mathrm{BAP} 4 \mathrm{ppm}, \mathrm{D}=\mathrm{MS}+\mathrm{GA}_{3} 2 \mathrm{ppm}+$ BAP 2 ppm + IBA 1 ppm, EH = Eksplan Hidup, EK = Eksplan Kontaminasi, EB = Eksplan Browning, EM = Eksplan Memanjang, EA = Eksplan Berakar, ET $=$ Eksplan Bertunas.

\section{Persen Eksplan Hidup}

Dari tabel 1 di atas, dapat dilihat bahwa pada perlakuan $\mathrm{MS}+\mathrm{GA}_{3} 2 \mathrm{ppm}$ memiliki persen hidup $100 \%$, pada perlakuan ini tidak terdapat eksplan yang terkontaminasi. media MS 0 (kontrol) memiliki persen hidup $85 \%$, pada perlakuan ini terdapat 1 eksplan yang terkontaminasi. media MS + BAP 4 ppm memiliki persen hidup $71 \%$, pada perakuan ini terdapat 2 eksplan yang terkontaminasi dan pada media MS + $\mathrm{GA}_{3} 2 \mathrm{ppm}+\mathrm{BAP} 2 \mathrm{ppm}+\mathrm{IBA} 1 \mathrm{ppm}$ memiliki persen hidup $42 \%$, pada perlakuan ini terdapat 4 eksplan yang terkontaminasi.

\section{Persen Eksplan Kontaminasi}

Berdasarkan pengamatan yang dilakukan sampai akhir penelitian menunjukkan bahwa tidak semua eksplan

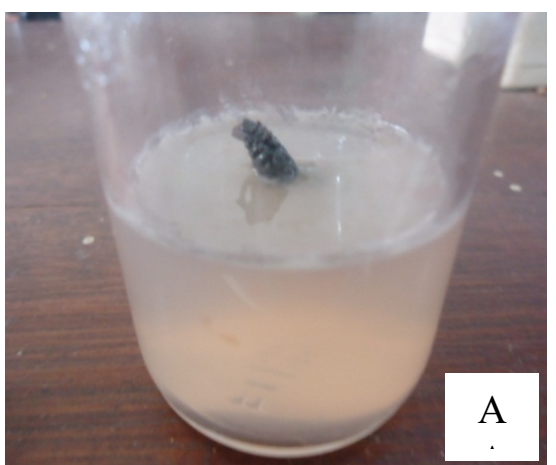

dapat bertumbuh dengan baik dikarenakan kontaminasi. Dalam penelitian ini kontaminasi terjadi pada eksplan, juga terjadi pada media. Media yang telah terkontaminasi akan menjadi penghambat untuk pertumbuhan embrio hingga embrio mati.

Pada media $\mathrm{MS}+\mathrm{GA}_{3} 2 \mathrm{ppm}+\mathrm{BAP} 2$ ppm + IBA 1 ppm memiliki persen kontaminasi $58 \%$, pada perlakuan ini terjadi pada eksplan kontaminasi yang paling tinggi dibandingkan dengan perlakuan lainnya. media MS + BAP 4 ppm memiliki persen kontaminasi 29\%, media MS 0 (kontrol) memiliki persen kontaminasi $15 \%$ dan pada media MS + $\mathrm{GA}_{3} 2$ ppm memiliki persen kontaminasi $0 \%$, pada perlakuan ini tidak terdapat eksplan yang terkontaminasi.

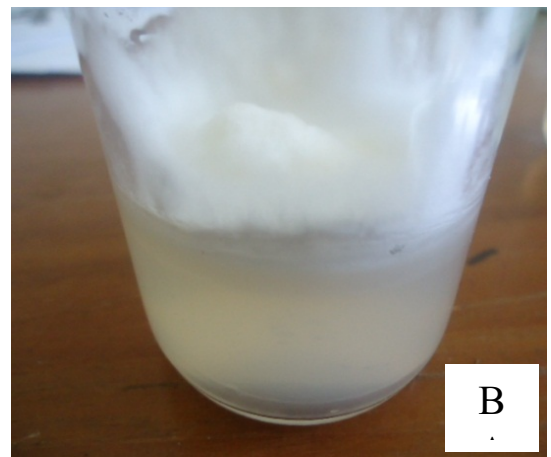

Gambar 1. Penampilan eksplan yang terkontaminasi. (A) kontaminasi karena bakteri, (B) kontaminasi karena jamur. 


\section{Persen Eksplan Browning}

Pencoklatan (browning) merupakan proses pembentukan pigmen berwarna kuning yang akan segara berubah menjadi coklat gelap yang dipicu oleh reaksi oksidasi yang dikatalisis oleh enzim fenol oksidase atau polifenol oksidase. Dari hasil pengamatan persen browning pada tiap perlakuan pada media $\mathrm{MS}+\mathrm{GA}_{3} 2$ ppm + BAP 2 ppm + IBA 1 ppm memiliki persen eksplan browning $71 \%$, pada perlakuan ini terdapat eksplan browning yang paling tinggi dibandingkan dengan perlakuan yang lain. pada media $\mathrm{MS}+\mathrm{GA}_{3} 2 \mathrm{ppm}$ memiliki persen eksplan browning 57\%, pada media $\mathrm{MS}+\mathrm{GA}_{3} 2 \mathrm{ppm}$ memiliki persen eksplan browning $42 \%$, dan pada media MS + BAP 4 ppm memiliki persen eksplan browning 14\%, pada perlakuan ini terdapat eksplan browning yang persentasinya rendah yaitu terjadi pada 1 eksplan yang browning.

\section{Persen Eksplan Memanjang}

Dari hasil pengamatan, embrio sebelum membentuk akan terlebih dahulu memanjang ukurannya. Pada perlakuan media $\mathrm{MS}+\mathrm{GA}_{3} 2 \mathrm{ppm}$ rata-rata pertumbuhan embrio adalah $\pm 2,5 \mathrm{~cm}$. ppm umur tanam pada saat embrio Media tanam pada perlakuan $\mathrm{MS}+\mathrm{GA}_{3} 2$ memanjang adalah tumbuh pada minggu ketiga. Pada perlakuan media MS 0 (kontrol) rata-rata pertumbuhan embrio adalah $\pm 1,5 \mathrm{~cm}$. media tanam pada perlakuan MS 0 (kontrol) umur tanam pada saat embrio memanjang adalah tumbuh pada minggu kelima. Pada perlakuan media MS + BAP 4 ppm ratarata pertumbuhan embrio adalah $\pm 0,8$ $\mathrm{cm}$. media tanam pada perlakuan MS + BAP 4 ppm umur tanam pada saat embrio memanjang adalah tumbuh pada minggu kedelapan. Pada perlakuan media MS + $\mathrm{GA}_{3} 2 \mathrm{ppm}+\mathrm{BAP} 2 \mathrm{ppm}+\mathrm{IBA} 1 \mathrm{ppm}$ rata-rata pertumbuhan embrio $\pm 0,5 \mathrm{~cm}$, media tanam pada perlakuan $\mathrm{MS}+\mathrm{GA}_{3}$ $2 \mathrm{ppm}+$ BAP $2 \mathrm{ppm}+\mathrm{IBA} 1 \mathrm{ppm}$ umur tanam pada saat embrio memanjang adalah tumbuh pada minggu ketujuh. Dari hasil pengamatan presentasi pemanjangan embrio pada media $\mathrm{MS}+\mathrm{GA}_{3} 2 \mathrm{ppm}$ persen pemanjangan embrio $100 \%$, pada media MS 0 (kontrol) persen pemanjangan embrio $85 \%$, pada media $\mathrm{MS}+\mathrm{BAP} 4 \mathrm{ppm}$ persen pemanjangan embrio $71 \%$, dan pada media $\mathrm{MS}+\mathrm{GA}_{3}$ $2 \mathrm{ppm}+\mathrm{BAP} 2 \mathrm{ppm}+\mathrm{IBA} 1 \mathrm{ppm}$ persen pemanjangan embrio $14 \%$.
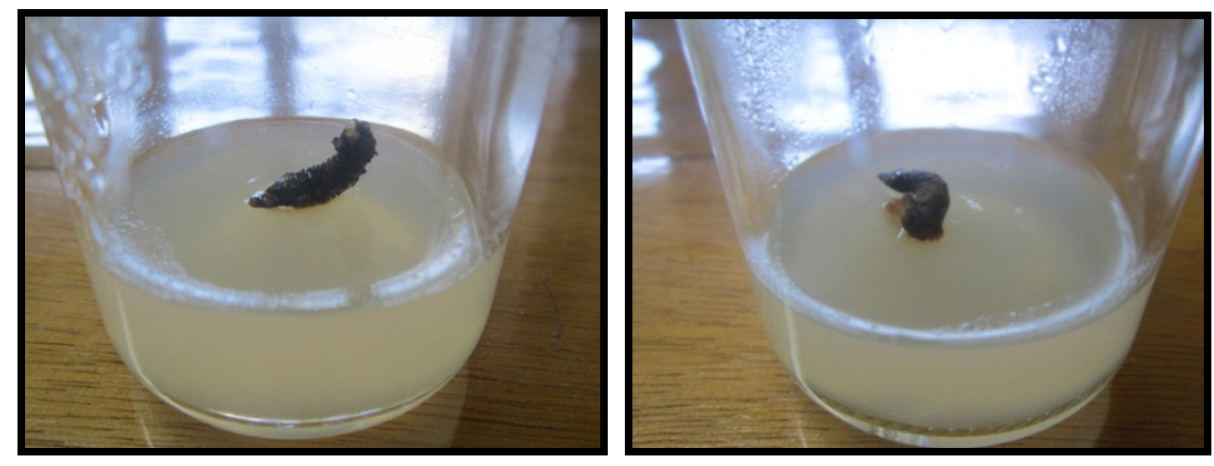

Gambar 2. Penampilan Pertumbuhan dari embrio Intsia bijuga (A) MS 0, (B) MS $+\mathrm{GA}_{3} 2$ ppm 


\section{Persen Eksplan Berakar}

Pada media $\mathrm{MS}+\mathrm{GA}_{3} 2 \mathrm{ppm}$ memiliki rata-rata pemanjangan akar adalah $\pm 0,8-2 \mathrm{~cm}$, dan akar terlihat memanjang. persen eksplan berakar pada media $\mathrm{MS}+\mathrm{GA}_{3} 2 \mathrm{ppm}$ lebih banyak menginduksi akar yang persentase sebesar $71 \%$ dibandingkan dengan perlakuan yang lainnya. Pembentukan akar pada perlakuan $\mathrm{MS}+\mathrm{GA}_{3} 2 \mathrm{ppm}$ pada umur tanam adalah \pm 60 hari (Gbr. 2B). Pada media MS 0 (kontrol) memiliki rata-rata pemanjangan akar adalah $\pm 0,5-$ $0,8 \mathrm{~cm}$, persen eksplan berakar pada media MS 0 (kontrol) sebesar 42\% dan juga pada media MS 0 (kontrol) umur tanam adalah \pm 80 hari (Gbr. 2A). Pada media $\mathrm{MS}+$ BAP 4 ppm belum mengalami perkembangan akar secara baik karena akar masih terjadi proses inisiasi akar, pada akar belum terdapat cabang-cabang akar yang muncul. Pada media MS + BAP 4 ppm tanaman dengan umur tanam \pm 43 hari, rata-rata pemanjangan akar adalah $0,1-0,5 \mathrm{~cm}$. pada media $\mathrm{MS}+\mathrm{GA}_{3} 2 \mathrm{ppm}+\mathrm{BAP} 2$ ppm + IBA 1 ppm, perlakuan ini juga belum mengalami perkembangan akar secara baik karena akar masih terjadi proses inisiasi akar, belum terdapat cabang-cabang akar yang muncul, dan juga terdapat kalus pada eksplan. Pada kedua perlakuan yaitu MS + BAP 4 ppm dan $\mathrm{MS}+\mathrm{GA}_{3} 2 \mathrm{ppm}+\mathrm{BAP} 2 \mathrm{ppm}+$ IBA 1 ppm menginduksi akar dengan persentasi $28 \%$ (Gbr. 2C).

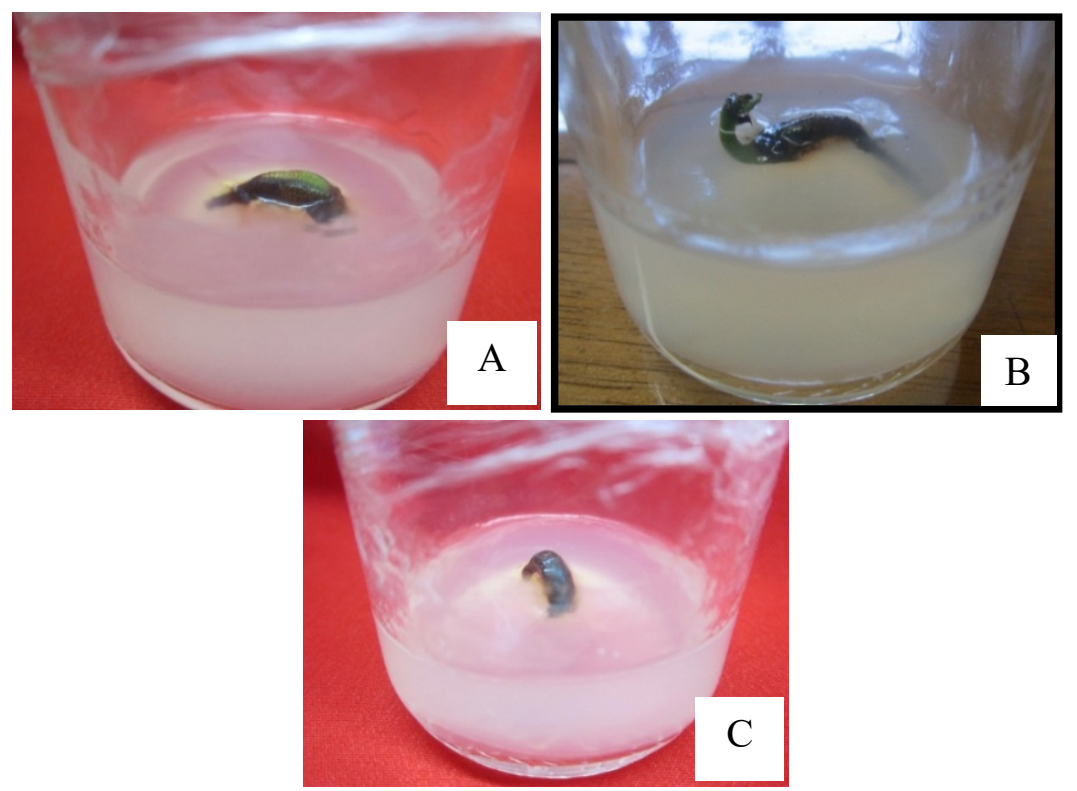

Gambar 3. Penampilan Eksplan Berakar dari embrio Intsia bijuga (A) MS 0, (B) $\mathrm{MS}+\mathrm{GA}_{3}$ $2 \mathrm{ppm},(\mathrm{C}) \mathrm{MS}+\mathrm{GA}_{3} 2 \mathrm{ppm}+\mathrm{BAP} 2 \mathrm{ppm}+\mathrm{IBA} 1 \mathrm{ppm}$

\section{Persen Eksplan Bertunas}

Pengamatan yang dilakukan dari minggu pertama hingga minggu ketujuh, pada perlakuan media $\mathrm{MS}+\mathrm{GA}_{3} 2 \mathrm{ppm}$ pertumbuhan tunas terjadi pada umur 65 hari dengan rata-rata pertumbuhan tunas sebesar $\pm 2 \mathrm{~cm}$. Selain munculnya akar, 
pada eksplan tersebut terdapat daun. Pertumbuhan tunas yang mulai tumbuh dan berkembang pada Perlakuan MS + $\mathrm{GA}_{3} 2$ ppm mencapai 57\% (Gbr. 4B).

Pada perlakuan media MS 0 (kontrol) pertumbuhan tunas terjadi pada umur 70 hari dengan rata-rata pertumbuhan tunas sebesar $\pm 0,2 \mathrm{~cm}$. Dari Eksplan embrio merbau yang ditanam pada media MS 0 mampu menumbuhkan tunas dengan persen eksplan bertunas sebesar 28\%, walaupun tunas yang tumbuh tidak berkembang dengan baik (Gbr. 4A).

Pada media MS + BAP 4 ppm pengamatan yang dilakukan dari minggu pertama hingga minggu ke tujuh, pada perlakuan $\mathrm{MS}+\mathrm{BAP} 4 \mathrm{ppm}$ pertumbuhan tunas terjadi pada umur 80 hari dengan rata-rata pertumbuhan tunas sebesar $\pm 0,3 \mathrm{~cm}$ dilihat pada (Gbr. 4C).

Pada media $\mathrm{MS}+\mathrm{GA}_{3} 2 \mathrm{ppm}+\mathrm{BAP} 2$ ppm + IBA 1 ppm pengamatan yang dilakukan dari minggu pertama hingga minggu ke tujuh, pada perlakuan MS + $\mathrm{GA}_{3} 2 \mathrm{ppm}+\mathrm{BAP} 2 \mathrm{ppm}+\mathrm{IBA} 1 \mathrm{ppm}$ pertumbuhan tunas terjadi pada umur 86 hari dengan rata-rata pertumbuhan tunas sebesar $\pm 0,2 \mathrm{~cm}$, pertumbuhan tunas belum muncul secara baik ke permukaan media, hanya terdapat eksplan yang mengalami tumbuh kalus pada permukaan media dilihat pada (Gbr. 4D).

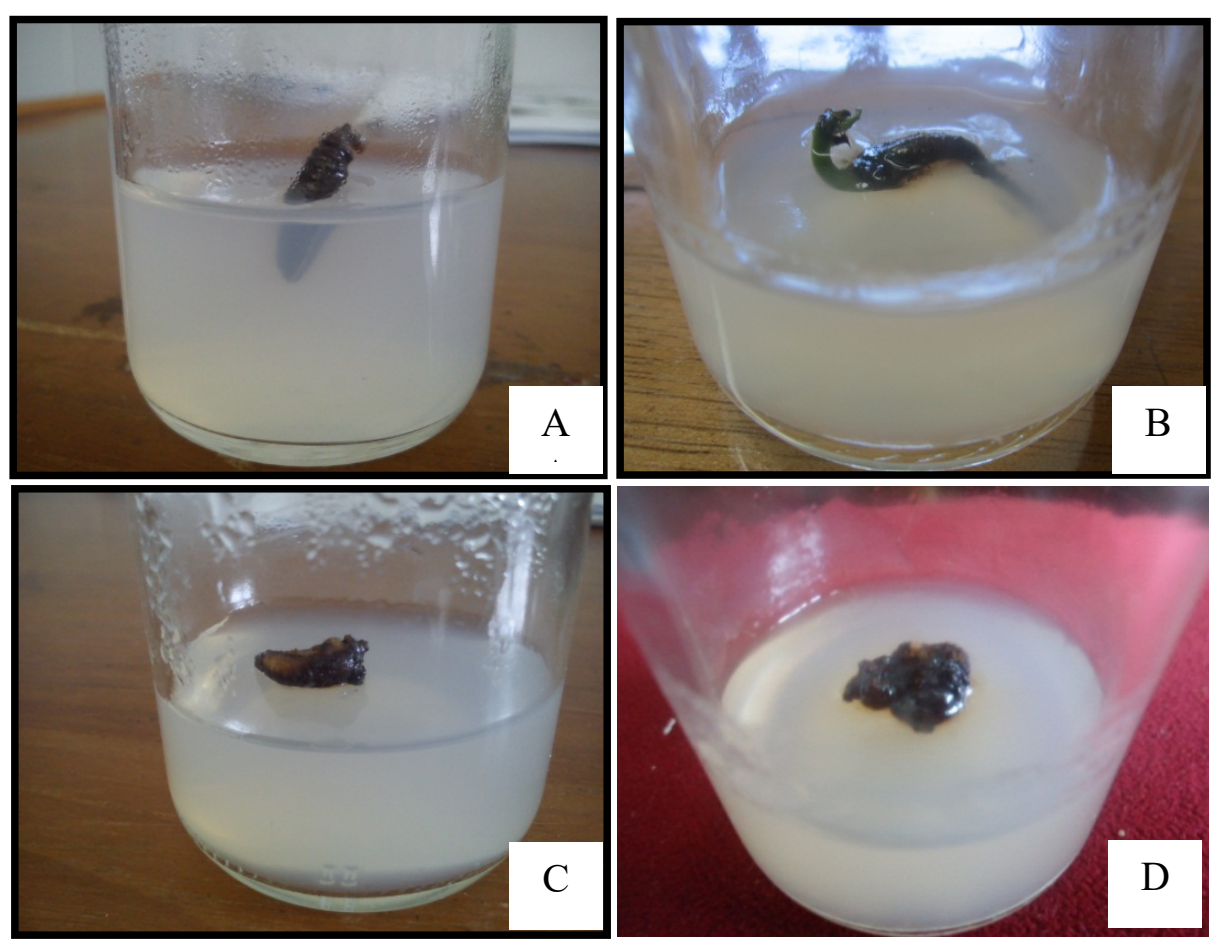

Gambar 4. Penampilan pertumbuhan tunas pada embrio Intsia bijuga (A) MS 0 (Kontrol), (B) $\mathrm{MS}+\mathrm{GA}_{3} 2 \mathrm{ppm},(\mathrm{C}) \mathrm{MS}+\mathrm{BAP} 4 \mathrm{ppm},(\mathrm{D}) \mathrm{MS}+\mathrm{GA}_{3} 2 \mathrm{ppm}+\mathrm{BAP} 2$ ppm + IBA 1 ppm.

\section{PEMBAHASAN}

Kontaminasi dan browning masih Kontaminasi tetap terjadi walaupun merupakan kendala dalam penelitian ini. prosedur sterilisasi telah dilakukan secara 
benar. Kemungkinan dapat disebabkan oleh adanya mikroorganisme yang terbawa dalam jaringan eksplan tanaman yang digunakan. Browning terjadi pada semua perlakuan yang diamati yaitu media MS 0 (kontrol), MS $+\mathrm{GA}_{3} 2 \mathrm{ppm}$, $\mathrm{MS}+\mathrm{BAP} 4 \mathrm{ppm}$ dan media $\mathrm{MS}+\mathrm{GA}_{3} 2$ ppm + BAP 2 ppm + IBA 1 ppm. Browning atau pencoklatan terjadi akibat reaksi oksidasi fenol. Kehadiran senyawa fenolik ini akan menghambat pertumbuhan dari eksplan. Untuk mengatasi terjadinya browning dapat dilakukan dengan menambahkan senyawa arang aktif kedalam media yang digunakan, namun pada penelitian ini tidak menggunakan senyawa arang aktif yang bertujuan untuk terhindar dari browning pada media tumbuh maupun eksplan.

Berdasarkan hasil pengamatan yang diperoleh pada percobaan $\mathrm{MS}+\mathrm{GA}_{3} 2$ ppm, embrio merbau menghasilkan panjang akar dengan rata-rata adalah 2 $\mathrm{cm}$. Hasil dari kontrol dan juga pemberian zat pengatur tumbuh MS 0, MS + BAP 4 ppm, dan $\mathrm{MS}+\mathrm{GA}_{3} 2 \mathrm{ppm}+\mathrm{BAP} 2 \mathrm{ppm}$ + IBA 1 ppm belum menghasilkan tunas yang signifikan. Hal ini terjadi karena konsentrasi zat pengatur tumbuh yang diberikan masih kecil. Pada perlakuan ini tidak menggunakan kinetin, jika sitokinin diberikan dengan konsentrasi yang tinggi pada tumbuhan maka akan banyak tumbuh tunas (Budiyanto 2013).

Konsentrasi pada perlakuan $\mathrm{MS}+\mathrm{GA}_{3}$ 2 ppm telah menghasilkan pertumbuhan tunas. Kinetin merupakan zat pengatur tumbuh golongan sitokinin. Sitokinin merupakan hormon tumbuhan turunan adenin yang berfungsi untuk merangsang pembelahan sel dan diferensiasi mitosis, disitensis pada ujung akar dan ditranslokasi melalui pembuluh xylem.
Aplikasi untuk merangsang tumbuhnya tunas pada kultur jaringan atau pada tanaman induk, namun sering tidak optimal pada tanaman dewasa (Budiyanto 2013).

Kalus adalah sekumpulan sel amorphous (tidak terbentuk atau belum terdiferensiasi) yang terbentuk dari sel-sel yang membelah secara terus menerus. Kalus dapat diperoleh dari bagian tanaman seperti akar, batang dan daun (Wikipedia 2010). Pembentukan kalus tidak selalu diharapkan bila diferensiasi untuk membentuk akar dan tunas tidak terjadi.

Disamping membentuk kalus, pemberian BAP pada kultur biji juga menyebabkan terjadinya tunas dan akar, walaupun pertumbuhan akar baik dalam jumlah, panjang akar maupun pemanjangan tunas tidak sebaik seperti pada perlakuan $\mathrm{GA}_{3}$. Berbeda yang ditampakkan pada kulur embrio tanaman merbau, pemberian BAP menyebabkan pertumbuhan akar dapat terjadi walau tidak sebaik pada pemberian $\mathrm{GA}_{3}$. Demikian juga pembentukan tunas tidak terjadi, baik pada pemberian BAP, IBA maupun $\mathrm{GA}_{3}$. Pada pertumbuhan kultur yang lebih cepat tumbuh umumnya adalah kultur biji dibandingkan dengan kultur embrio karena biji memiliki cadangan makanan yang terdapat pada kotiledon sedangkan pada embrio tidak kotiledon.

Sitokinin berfungsi meningkatkan pembelahan sel, pertumbuhan sel dan perkembangan kultur sel tanaman terutama pada pembentukan tunas (Wattimena 1987). Peran sitokinin dalam pembelahan sel dan pembentukan tunas ditunjukkan juga pada penelitian (Ardiana 2009), dimana penambahan BAP 4 ppm pada MS memberikan hasil yang terbaik 
dalam pembentukan kalus dan tunas pada eksplan kotiledon melon. Pada penelitian yang digunakan memperlihatkan bahwa pemberian BAP 4 ppm memberikan respon yang nyata terhadap pemanjangan embrio, respon yang digunakan belum nampak pada pertumbuhan tunas secara in vitro yang menggunakan eksplan embrio merbau (Intsia bijuga).

Giberelin terdapat pada berbagai organ dan jaringan tumbuhan seperti akar, tunas, mata tunas, daun, bunga, bintil akar dan buah (Wattimena 1987). Giberelin berpengaruh terhadap sifat genetik pada perkecambahan yaitu merangsang pembelahan sel dan pembesaran sel. Peran giberelin dalam perpanjangan sel tanaman sangat ditampakkan pada kultur embrio tanaman merbau. Hasil yang sama didapatkan pada penelitian Syafii dan Sutrisna (2006), bahwa penambahan $\mathrm{GA}_{3}$ 2 ppm sangat efektif mendorong pertumbuhan tunas pada eksplan biji Anggrek Bulan (Phalaenopsis amabilis BL).

Pada kultur embrio kombinasi antara zat pengatur tumbuh sitokinin, auksin dan giberelin membentuk hasil terbaik dalam pembentukan tunas maupun daun, sedangkan pembentukan akar menjadi agak terhambat dibandingkan dengan pemberian $\mathrm{GA}_{3}$ tunggal. Sebaliknya pembentukan tunas pada pemberian sitokinin tunggal maupun tidak sebaik apabila keduanya digabungkan dengan IBA.

\section{DAFTAR PUSTAKA}

Ardiana DW. 2009. Pemberian Benzil Amino Purin (BAP) untuk memacu pertumbuhan kalus dan tunas kotiledon melon. Buletin Teknik Pertanian 14 (2) $50-53$.

Budiyanto. 2013. Teknik kultur jaringan pada tanaman induk. Kanisius. Jakarta.

Muhiklaten. 2011. Pengertian kultur jaringan dan metode kultur jaringan. PAU Bioteknologi. Universitas Indonesia. Jakarta.

Syafii B dan Sutrisna. 2006. Pengaruh pemberian giberelin $\left(\mathrm{GA}_{3}\right)$ dan air kelapa terhadap perkecambahan bahan biji anggrek bulan (Phalaenopsis amabilis BL) secara in vitro. Jurnal Biogenensis 2 (2) : $41-46$.

Wattimena G A. 1987. Zat pengatur tumbuh tanaman. PAU Bioteknologi IPB. Bogor.

Wikipedia. 2010. Wikipedia bahasa indonesia Ensiklopedia Bebas. (Diambil dari http://wikipedia.org. 29 Juni 2011). 